\title{
Teodisee vraagstuk in Job as uitdaging aan die grense tussen samelewing (rein) en wildernis (onrein)
}

NGTT DEEL 55, NR 3 \& 4, 2014

\section{Pistorius, Hendrik Gerhardus}

Universiteit van Pretoria

Human, Dirk J

Universiteit van Pretoria

\section{ABSTRACT}

The question regarding theodicy in Job as a challenge in regard to the borders between society and wilderness

This article focuses on the first divine speech in Job (38-39:33). In this regard the first divine speech serves as polemics against the ruling Zeitgeist in post-exilic Israel. A message of hope, that urges Israel to focus her attention on the one sovereign God sprouts forth from it, morphing the first divine speech into a radical message of cultic and religious encouragement. The animals listed in Job 38-39:33 show similarities when their habitat is taken into account. Habitat outside of society and death as a conceptual location is linked to each other in various ways. The article attempts to show that concepts such as being clean or unclean is created through cultural processes of thought that links being clean with cosmic order and the presence of God. Cultic cleanness is linked with 'society'. The antitheses of 'society' is 'wilderness'. In Job 38-41 God cares for animals that live in the 'wilderness'. The negative associations that Israel have towards 'wilderness' now stands in direct contrast towards God's love and care.

In this regard Israel's perception of true cleanness and uncleanness is placed in the spotlight. Clean, unclean and right and wrong seems to be redefined and God claims authority over it all. Suffering, deserved or not and our negative feelings towards suffering is redefined, seeing that what we once thought was wrong and had negative feelings towards, just like uncleanness, now seems to be a part of the one sovereign God.

\section{TREFWOORDE}

Job 38 - 41, Godsredes in Job, teodisee-vraagstuk, rein, onrein
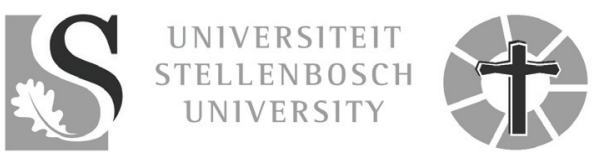


\section{KEYWORDS}

Job 38 - 41, dispute in Job, theodicy in Job, clean, unclean

\section{KONTAKBESONDERHEDE}

\section{HG Pistorius}

Fakulteit Teologie, Universiteit van Pretoria

Pretoria, 0002

hgpistorius@webmail.co.za

Prof DJ Human

Fakulteit Teologie, Universiteit van Pretoria

Pretoria, 0002

dirk.human@up.ac.za

\section{NOTE}

This article is the dissemination of a MA in Old Testament Studies under the supervision of Prof DJ Human at the University of Pretoria. Rev Pistorius is a postgraduate student in the Department of Old Testament Studies (UP). 


\section{INLEIDING}

In hierdie artikel word die Godsredes in Job 38-39:33 bespreek. Hoofstuk 38-39:33 dien as polemiek teen die heersende Zeitgeist in 'n na-ballingskapse Israel. Hierdie polemiek dien as 'n boodskap van hoop en rig Israel tot aanbidding van God. Die boek Job neem moeilike teologiese en Ou-Testamentiese vraagstukke op, spesifiek met betrekking tot die teodisee en die vergeldingsdogma en weier om goedkoop en oppervlakkige antwoorde te aanvaar (Brueggemann, 2003:293). Alhoewel lyding 'n deurlopende tema in die boek Job is, handel die verhaal nie primêr oor lyding nie, maar oor die verstaan van God (Von Rad, 1972:221). Die aktualiteit van die verhaal van Job gaan gepaard met Job en Job se vriende se vrae en redenasies wat 'n simbool word van die geloofsgemeenskap se vrae rondom die aard van God, regverdigheid, lyding, vergeldingsleer en uiteindelik die relasie tussen God en mens.

\section{PROBLEEMSTELLING EN DOELSTELLING}

Alhoewel lyding nie die primêre doel van die verhaal is nie, dien dit nietemin as 'n belangrike invalshoek tot die verstaan van lyding en die teodisee vraagstuk. Dit blyk of die kontemporêre Westers georiënteerde mens se verstaan van lyding verskil van die tradisionele gereformeerde siening daarvan en is dus in stryd met teologieë wat God as outoritêr en soewerein uitbeeld. ${ }^{1}$ Hierdie diskrepansie in die verstaan van lyding beïnvloed die interpretasie van die boek Job. 'n Kontekstuele lees van hoofstukke 38 - 39:33 bring vars insigte op die verstaan van lyding na vore met betrekking tot die ruimtes wat die verskillende diere in Job 38 - 39:33 habiteer.

Die beelde (spesifiek die diere) wat in Job 38 - 39:33 gebruik word as "antwoord" op die vrae van Job het'n sekere teologiese doel en kontekstuele bestemming (Keel, 1978:52). Hierdie kontekstuele bestemming is gefundeer in 'n sekere tyd en plek en het binne daardie konteks 'n spesifieke doel (Keel, 1978:52).

Die uitdaging tot verantwoordelike teologiese refleksie oor Job 38 - 39:33 staan in verband met die verstaan van die verskillende kontekste van die verhaal en van die boek self. In hierdie opsig poog die artikel nie om etlike en alle weë van redeneer ten opsigte van die tyd-ruimtelike aspek in die eerste Godsrede te bestudeer nie. Eerder het die artikel ten doel om nog 'n weg tot die verstaan van teodiseë te baan deur die eerste Godsrede te lees teen die agtergrond van kultiese reinheid/onreinheid.

Die karakter Job se vrae oor onverdiende lyding word beantwoord deurdat die outeur/s God se skeppende en soewereine hand skerp vergelyk met Job se tydruimtelike beperkings. Hierdie vergelyking vind plaas in die vorm van verskillende

1 Sien Yancey (1990 [1977]). 
diere wat genoem word. Hiérdie diere word aan die hand van die artikel geëvalueer in kategorieë van rein en onrein. Alhoewel die boek Job nie melding maak van kultiese reinheid en onreinheid nie, poog die artikel om kultiese reinheid en onreinheid te gebruik as metodologiese invalshoek en sodoende te verklaar hoekom juis hiérdie spesifieke diere gebruik word as antwoord op die eksistensiële vrae van die karakter Job.

\section{ENKELE SINKRONIESE EN DIAKRONIESE PERSPEKTIEWE}

Daar is ' $n$ historiese gaping tussen die vertelde tyd en die tyd van vertelling met betrekking tot die boek van Job. Die verhaal speel af in die voor-aardsvadertydperk. Die boek Job weerstaan enige eenvoudige historiese plasing (Brueggemann, 2003:302). Die boek is die resultaat van 'n lang proses van ontwikkeling (Gordis, 1965:19) ${ }^{2}$ en het waarskynlik ontstaan uit 'n sogenaamde antieke Job-legende, wat as die basis vir die Bybelse narratief dien (Pope, 1965:xxxi). ${ }^{3}$

Die boek Job word as wysheidsliteratuur geklassifiseer (Konkel, 2006:3). ${ }^{4}$ Wysheidsliteratuur is nie 'n spesifieke Gattung nie, maar eerder'n gerieflikheidsterm, wat onder andere na die kanoniese boeke Job, Spreuke, Prediker en sommige Psalms verwys (Konkel, 2006:3). Vir dié rede word die boek Job gekwalifiseer aan die hand van Gattungen, eerder as een spesifieke Gattung (Hartley, 1988:38). Albei Godsredes volg die algemene patroon van dispuut (Hartley, 1988:42). Die kern van die eerste Godsrede bestaan uit 'n lofprysing aan Jahwe as skepper en onderhouer. Deurdat hierdie lofprysing uit retoriese vrae bestaan, kry dit argumentatiewe eienskappe (Hartley, 1988:42).

Wat die struktuur van die boek Job betref, bestaan dit uit'n aantal dele, wat moontlik vroeër as onafhanklike vertellings funksioneer het (Wilson 2007:11). Daar is egter'n intensionele redaksionele eenheid met 'n koherente doel en teologiese betekenis in die boek (Wilson, 2007:11).

Die outeur(s) van die boek Job was bekend met verskillende lande se kulture, geografie, godsdiens, mitologiese tradisies en literatuur (Pope, 1965:xxxviii). Brueggemann (2003:294) noem dat die outeur van die boek nie net bekend was met ander antieke Nabye-Oosterse tekste nie, maar dat hy/sy/hulle uit hierdie sogenaamde "kulturele reservoirs" materiaal, gedagtes en motiewe getrek het. Sou die outeur(s) van die boek Job nie van die antieke Nabye-Oosterse tekste as bron(ne)

2 Sien Pope (1965:xxxi); Rowley (1970:9) en Murphy (1981:20).

3 Sien Wyatt (2001:144); Wilson (2007:2-3 \& 9-10) en Van Deventer (2009:672).

4 Sien Rowley (1970:6); Wilson (2007:5) en Walton (2007:333 \& 335). 
gebruik het nie, getuig die ooreenkomste ten minste op 'n soortgelyke kulturele, godsdienstige en literêre denk-atmosfeer en verwysingsraamwerk, waarin die boek tot stand gekom het.

\section{ENKELE TEOLOGIESE PERSPEKTIEWE}

In die verhaal van Job is Job en sy vriende se doel nie om historiese figure uit te beeld nie, maar eerder om tradisionele wysheidskonsepte te verteenwoordig (Von Rad, 1972:210, 216). In besonder is een van hierdie wysheidskonsepte, die sogenaamde vergeldingsdogma. Hierdie dogma stipuleer dat daar 'n direkte korrelasie tussen die mens se gedrag en die mens se lot is (Clines, 1989:xxxix). Vir Job se vriende is Job se ervaring juis 'n bevestiging van die vergeldingsleer (Clines, 1989:xlii). Die vier vriende se benaderings tot die vergeldingsleer verskil, maar die teologiese uitgangspunt is dieselfde. Al die karakters (insluitend Job) in die boek Job pas die leerstelling van vergelding op Job se situasie toe, behalwe God (Dick, 2006:263). Die boek Job bevestig nie die vergeldingsteologie nie, maar keer dit ook nie af nie (Clines, 1989:xlvi). Eerder marginaliseer die teologieë van die boek Job die vergeldingsleer, aangesien die vergeldingsleer nie van toepassing is op die situasie van Job nie (Clines, 1989:xlvi).

Die boek Job spreek ook die teologiese probleem rondom die lyding van die regverdige individu aan. Alhoewel die boek Job die probleem rondom lyding aanspreek en sekere afleidings rondom lyding maak, spreek die boek primêr net een persoon se lyding aan (Clines, 1989:xxxviii). Gekonfronteer met die klaarblyklike sinnelose lyding van die karakter Job kan die leser nie anders as om vrae rondom God se regverdigheid (teodisee), in dié situasie te vra nie (Pope, 1965:x). Die teofanie in hoofstuk 38 - 41 bestaan nie daaruit om antwoorde te bied op die teodiseevraagstuk nie, maar dit funksioneer om die afstand tussen menslike verstaansvermoë en goddelike majesteit te beklemtoon (Matthews \& Moyer, 1997:183). ${ }^{5}$

\section{DIE TEOFANIE: JOB 38 - 41 EN DIE DIERE- IN DIE ANTIEKE NABYE OOSTE}

Hierdie artikel fokus op die eerste Godsrede (Job 38:36-39:33). Ek omskryf die rol, plek en simboliese funksie van diere in die antieke Nabye Ooste en die Israelitiese kultuur. Hier kom elke dier in Job 38:36 - 3:33, aan die orde.

5 Sien Dick (2005:266). 


\section{Ibis en haan (38:36)}

Die Hebreeuse woord wat in Job 38:36 vertaal word met ibis is, tuhôt (Hartley, 1988:503). Tuhôt word as 'n transliterasie van die naam vir die Egiptiese god Thoth beskou (Pope, 1965:256; Rowley, 1970:316; Gordis, 1978:452). Die ibis was die heilige dier van Thoth en was simbolies van hom (Rowley, 1970:316). ${ }^{6}$ As ibis het Thoth onder andere die take van die god van wysheid vervul (Wyatt, 2001:59; Walton, 2007:340). Volgens antieke wysheid het die ibis veranderings in die weer aangekondig (Hartley, 1988:503), asook die Nylrivier se vloed aangekondig (Gordis, 1978:453). Antieke wysheid beskou die ibis dus as 'n voël van besondere wysheid (Gordis, 1978:453). Die tipe ibis wat hier ter sprake kom, is waarskynlik die Ibis Religiosa (wit/heilige ibis) of die Ibis Falcinellus (glansibis). ${ }^{7}$ Die ibis is as 'n onrein voël in Israelitiese godsdiens beskou (Lev 11:17).

Die Hebreeuse woord in Job 38:36 wat vertaal word met "haan" (NAV) is sekwi (Gordis, 1978:452). Antieke wysheid bepaal dat die haan die koms van reën kon voorspel, asook die begin van die dag aankondig (Pope, 1965:256). Hoenders maak deel uit van die vleisvoorraad, wat geëet is deur voor-ballingskapse Judeërs (Houston, 1993:47). Sekere Rabbiniese tradisies meld die feit dat hoenders nie in Jerusalem toegelaat was nie, omdat hulle moontlik iets onreins kon uitskrop (Wood, 2009 [1869]:424). ${ }^{8}$

Hoofstuk 38:36 noem die ibis en die haan. Die haan het wysheid oor dag en nag en die ibis oor seisoenale veranderinge (Keel, 1978:60-61). Die diere verteenwoordig wysheid wat God skenk en wat strek ten alle tye en tydperke. Terselfdertyd beskik hierdie twee voëls oor wysheid wat mense nie het nie.

\section{Leeu en kraai (39:1-3)}

In Job 39:1 word die Hebreeuse woorde lelabı̆yā en kepǐriem, onderskeidelik met leeuwyfie en leeuwelpie vertaal.

Die jag van leeus in die antieke Nabye Ooste deur die koning was in lyn met die simboliek wat leeus as vyande van die koninklike familie, regering en orde in die samelewing/skepping inneem. Diekoninklike jag van dieleeu as vyand van diekoning en die geskape orde in die samelewing het groot simboliese waarde gehad (Firmage,

$6 \quad$ Sien Gordis (1978:452); Wyatt (2001:58); Konkel (2006:223).

7 Die Egiptiese glansibis toon merkwaardige ooreenkomste met die Suid-Afrikaanse glansibis, Pegadis Falcinellus (Sinclair \& Davidson, 1995:36).

8 Hoe prakties hierdie wet was en hoe pragmaties dit was, is onseker, veral as 'n mens die hoeveelheid handelaars in Jerusalem in ag neem wat nie Jode was nie. 
1992:1109-1167). Wanneer die koning die leeu doodmaak, dien dit simbolies deurdat dit byvoorbeeld die Assiriese koning se troonbestyging simboliseer, asook die skep en handhawing van orde in die skepping deur die koning (Figuur 6a-b) (Firmage, 1992:1109-1167). Die koning vervul 'n kultiese funksie (simbolisering van die godheid wat chaos oorwin en orde vestig) (Dick, 2006:252). Op dié wyse word die koning regeerder en regeer hy op dieselfde vlak as die godheid Erra (Dick, 2006:244).

Levitikus 11:27 se bepalings klassifiseer leeus as onrein diere, omdat die leeu handagtige (Yad) (blykbaar onnatuurlike) pote het. Die leeu is 'n roofdier wat soms aas en hierdie feit dra by tot die dier se onrein status.

Die leeus in Job 39:1 kom voor asof hulle beskerming en sorg nodig het (Wilson, 2007:439). Tog is leeus goed toegerus om hulle prooi te vang. Die versorging van die leeu deur God dui op God se unieke versorging van sy skepping (Rowley, 1970:317). God se versorging van die leeus skilder die kompleksiteit van die skepping en hoe skynbare goedheid en boosheid (vang van onskuldige prooi en God se hulp daarin) inmekaarweef.

In Job 39:3 (Ps 147:9) word God se sorg ook vir kraaie (ōrēb - die swart een) bevestig. Hierdie woord (ōrēb) verwys waarskynlik na al die kraai-agtige voëls in Israel (Ferguson, 1974:54). Hierdie drie spesies is Corvus Corax (Europese kraai), Corvus Ruficollis (bruinnekkraai) en Corvus Rhipidurus (waaierstertkraai) (Ferguson, 1974:54). Kraaie is onrein (Lev 11:14). Die kos wat kraaie eet, strek vanaf klein en swak diertjies tot aas en rommel (Hartley, 1992:159). Dit is moontlik dat juis dié kos, wat die kraaie eet, hulle hierdie onrein status gee (Thompson, 1974:197; Porter, 1976:87). Vir die antieke mens was die bene van 'n mens wat gesterf het besonder belangrik (Keel, 1997[1972]:66). Sou die bene van 'n gestorwene voortbestaan, sou hierdie persoon nog 'n mate van bestaansreg hê (Keel, 1997[1972]:66). Daarom het vele antieke Nabye-Oosterse mense ander aangemoedig om nie hulle bene na hulle dood te vernietig of te verwyder nie (Keel, 1997[1972]:66). Kraaie het bene van byvoorbeeld gesneuweldes geëet en dit dra by tot die weersin in hierdie diere.

Kraaie en leeus het by dieselfde karkaste gevreet. God sorg vir albei hierdie diere, alhoewel albei hierdie diere met dood, dus onreinheid en by implikasie wanorde geassosieer word (Keel, 1978:82; Hartley, 1988:504). Die gedeelte toon dat selfs diere, soos leeus en kraaie wat deur mense verpes word, in God se sorg leef (Habel, 1975:213). 


\section{Ibeks en hert (39:4-7)}

Job 39:4 verwys na die ibeks en 'n tipe takbok/hert (Pope, 1965:259). Die Hebreeuse woord wat hier gebruik word, is yaeil (letterlik: bokke van die klip/berg) (Reyburn, 1992:719). Volgens Pope (1965:259) kan dié ibeks as Capra ibex nubiana/Nubiese ibeks geïdentifiseer word (Figuur 7a). Die habitat van die ibeks is bergagtige hange en randjies (Hartley, 1988:506). Die tweede tipe bok wat in Job 39:4 genoem word, is die takbok/hert en word in die NAV met "wildsbokke" vertaal. Die takbok ('ayyal/'ayyalâ) van die Ou-Testamentiese tydperk is die Mesopotamiese damhert/ fellow-deer (Dama Mesopotamica) (Ferguson, 1974:28). ${ }^{9}$ Die simbole van die "here van die volstruise" en die "here van die ibekse" was algemene verskynsels in die Ystertydperk in Palestina. In die Babiloniese mitologiese motiewe word die god Marduk met die Ibeks geassosieer en staan so binne die tradisie van die "here van die diere" (Keel, 1978:87-90). Job 39:4-7 plaas Jahwe binne hierdie motief (Keel 1978:87-90). Die motief van die "here van die Ibekse" is 'n populêre motief deur die hele antieke nabye ooste (Keel, 1978:91-93). So ook is seëls met die "here tussen die ibekse" in Noord-Israel (tiende tot agste eeu vC) gevind (Keel, 1978:92). Die ikonografiese motief blyk algemeen te wees en so ook die teologiese betekenis dat die "here van die diere" soewerein teenoor die skepping staan. In Job 38 - 41 staan Jahwe binne die tradisie van die "here van die diere" (Dick, 2006:266).

Alhoewel die damhert en die ibeks volgens kultiese wette eetbaar was (Deut 14:5) en geëet is, is hierdie wildsbokke nie as offers gebring nie (Anderson, 1992:870-886). ${ }^{10}$ Ten spyte van die feit dat die ibeks in die familie-groep Antilopus geklassifiseer word, die damhert in die groep Cervidae en die gedomestiseerde bok in die Caprinaegroep, is al drie hierdie spesies egter bokagtig van aard en vir die doel van hierdie studie sowel as die verwysingsraamwerk van die antieke mens vergelykbaar.

Antieke herders was bekend met hulle kuddes se lamgewoontes, maar die presiese gebeure rondom wildsbokke se geboortes was vir die antieke mens 'n raaisel (Alden, 1993:382; Van Deventer, 2009:726). Job 39:4-7 se presiese beskrywing van die geboorte en eerste dae van die wildsboklammers dui daarop dat God bekend is met die lamgewoontes. Hierdie teenwoordigheid van God by die geboorteproses dui op die besorgdheid van God oor die jong lammers (Wilson, 2007:440). Die besorgdheid en voorsiening van God oor die skepping en meer spesifiek die wildsbokke is 'n

9 Die Mesopotamiese damhert het in Israel gedurende die $19^{\text {de }}$ eeu uitgesterf en kom vandag slegs in Iran voor (Ferguson, 1974:28).

10 In Egipte was die teenoorgestelde waar. Hiér was die gesogte diere gejag en geoffer, byvoorbeeld buffels, wildsbokke, gaselle en Ibekse (Firmage, 1992:1109-1167). 
algemene motief in die antieke Nabye Ooste. Gode en godinne wat plante uit hulle liggame laat spruit om kos te voorsien, is algemeen (Keel, 1998:20-21).

Die eksplisiete beskerming van wildsbokke teen gevaar is ook 'n motief wat in die Bronstydperk (2000 - $1200 \mathrm{vC}$ ) bekend was. ${ }^{11}$ Dit is moontlik dat die beskerming van die ibekse deur die gode 'n metafoor is dat die gode voorspoed en vrugbaarheid handhaaf en teen magte van boosheid en chaos beskerming bied. Dus handhaaf die godheid orde binne die menslike samelewing deur gebruik te maak van 'n dier, die ibeks, wat eksplisiet buite menslike samelewing woonagtig was. Die lammers van wildsbokke kan ook gesien word as 'n seën van God (Keel, 1998;75). Hierdie afleiding bestaan na aanleiding van die ikonografiese aanduidings rondom die maan embleem van Haran wat nou geassosieer word met wildsbokooie en jong lammers (Keel, 1998:75-76). Dit is moontlik dat die fases van die maan as tydsberekening en simbool kan dien van seisoenale gebeurtenisse, soos lamtyd onder wildsbokke. Job 39:5 verwys na die tydperk van dragtigheid van wildsbokke, asook lamtyd. In hierdie opsig is die motief, dat God nie net bewus is van hierdie tydperke nie, maar dit ook bepaal in lyn met antieke Nabye-Oosterse motiewe van die maangod.

God se sorg is net so kompleks soos God se skepping. Die lammers se vryheid, ten spyte van skeppingsorde, beklemtoon die kompleksiteit van die skepping. God sorg vir die roofdier (leeu) en die prooi (wildsbok).

\section{Wildedonkie (39:8-11)}

In Job 39:8-11 is die wildedonkie (pere') ter sprake, waarskynlik Equus hemionus hemippus (Siriese wildedonkie) (Ferguson, 1974:24). ${ }^{12}$ Volgens Levitikus 11:2-3 is die donkie (ook wildedonkie) en perd onrein diere as gevolg van albei hierdie diere se soliede hoewe (Hartley, 1992:158). ${ }^{13}$ Die meeste van die Ou-Testamentiese tekste waar die wildedonkie genoem word, dui op dié dier se afsondering en eensaamheid (Alden, 1993:382). Job 39:9 meld die 'arābâ of soutvlaktes. Hierdie woord word vandag steeds gebruik om na die gebied tussen die Dooie See en die Golf van Akaba te verwys (Alden, 1993:384). Die habitat (soutvlaktes) van die wildedonkie is warm,

11 'n Silinderseël met 'n Siriese godin wat 'n ibeks aan die horing vashou en 'n leeu van die ibeks weghou, dien as voorbeeld van die godin se beskerming van wildsbokke (Keel, 1998:32).

12 Die Siriese wildedonkie het in die vroeg $20^{\text {ste }}$ eeu uitgesterf (Ferguson, 1974:24). Die Persiese wildedonkie (Equus hemionus onager) kom steeds voor, maar het waarskynlik nooit in antieke Israel voorgekom nie (Ferguson, 1974:24).

13 Tog was die wildedonkie se vleis in die res van die antieke Nabye Ooste gesog (Wood, 2009[1869]:282). 
droog en onbewoonbaar (Hartley, 1988:507). Die habitat van die wildedonkie is dus vyandig teenoor die mens se behoeftes tot oorlewing. In die antieke Nabye Ooste word diere as wys geag, omdat hulle die vermoë het om te oorleef in omstandighede waarin die meeste mense sou sterf (Crenshaw, 1981:27).

Die feit dat God in die posisie is om die soutvlaktes weg te gee, beklemtoon God se eienaarskap oor die soutvlaktes, 'n area wat nie deur die mens beheer of bewoon word nie (Wilson, 2007:441) en dus ook negatiewe assosiasies het.

Die wildedonkie en sy habitat is nie beheerbaar deur die mens nie (Keel, 1978:82). In hierdie opsig is die kommervrye lewe van die wildedonkie wat sy totale lewe oorlaat in die bevrydende sorg van God 'n kontras met die lewe van Israel wat ook deur God bevry is (Keel, 1978:67). Die wildedonkie wat in vrye dankbaarheid teenoor God leef, asook die habitat wat die wildedonkie bewoon staan in kontras met die verwagtings van die mens. Job se verlange na vryheid is nie in lyn met die teologiese helderheid en wysheid van die wildedonkie se lewe nie. Die wildedonkie dien as 'n simbool van 'n anti-samelewing. Hy is tevrede met die minste en altyd afhanklik van God. Die lewe van die wildedonkie plaas die mens se verwagtings met betrekking tot vryheid in perspektief, deurdat die wildedonkie nie waarborge tot sukses en die opberging van die materiële nastreef nie, maar deur eenvoud die vryheid geskenk deur God vier.

\section{Buffel (39:12-15)}

Job 39:12-15 fokus op die rêm (buffel), waarskynlik die Bos primigenius (Wenham, 1981:175), ${ }^{14}$ ook bekend as die Aurochs (Ferguson, 1974:26). As gevolg van die buffel se horings en liggaamlike grootte was dit 'n gevaarlike dier (Num 23:22; 24:8 en Ps 22:22). ${ }^{15}$ Dié dier is deur die hele antieke Nabye Ooste aangetref en het in afgeleë areas in noordelike Mesopotamië tot en met $900 \mathrm{vC}$ voorgekom (Firmage, 1992:1109-1167). ${ }^{16}$ Die buffel het krag in die antieke Nabye Ooste gesimboliseer (Habel, 1975:213), in besonder die horings van die buffel (Keel, 1997[1972]:86). Die krag, onbeheerbaarheid tesame met die vrugbaarheid wat die buffel gesimboliseer

14 Sien Pope (1965:260) en Alden (1993:385).

15 'n Sumeriese gesegde meld die gevaar wat die buffel inboesem. Keel (1997[1972]:88) haal dit soos volg aan: "When I had escaped the wild bull, I stood before the wild cow."

16 Die Bos primigenius het ook in Noord-Afrika en Europa voorgekom en het gedurende die $17^{\text {de }}$ eeu totaal uitgesterf (Ferguson, 1974:27). Andersen (1976:281) meen die presiese datum van uitwissing is 1627 . 
het, het die assosiasie met die god, Baal, vergemaklik wat 'n vrugbaarheidsrol ${ }^{17}$ in Kanaänitiese godsdiens vervul het (Wolff, 1978[1974]:39). ${ }^{18}$

Die gedomestiseerde bees en die buffel maak deel uit van die sub-familie groep Bovinae. Dit is dus nie vreemd oom vergelykings tussen die twee diere te trek nie. Die gedomestiseerde bees se totale lewe is deur die mens beheer en gereguleer. Die buffel beskik oor die fisieke krag om 'n goeie werkdier te wees, maar nie oor die gesindheid nie.

Uit 'n menslike perspektief blyk God dwaas te wees om 'n dier te skep met soveel $\mathrm{krag}$, maar wat nie ingespan kan word vir menslike gebruik (landbou doeleindes) nie (Hartley, 1988:508; Wilson, 2007:442). Die buffel se vryheid en krag bring perspektief op die rol van die mens in die skepping. Dit dui daarop dat die skepping vir God meer is as net 'n wyse om aan die mens se behoeftes te voldoen (Wilson, 2007:442).

\section{Ooievaar en volstruis (39:16-21)}

Job 39:16 maak melding van die Hebreeuse woord hâsîdâh (ooievaar). Die stam van dié Hebreeuse woord hâsîdâh is hesed (standvastige liefde, genade sagmoedigheid). Die ooievaar waarna hier verwys word, is moontlik die Ciconia-ciconia (witooievaar) (Ferguson, 1974:45). Volgens Levitikus 11:19 is die ooievaar onrein. Die witooievaar se voedsel bestaan grootliks uit klein diertjies en soms sekere plante (Hartley, 1992:160). Heelwaarskynlik het die feit dat die witooievaar prooi op ander diere daarmee te make dat dit 'n onrein klassifikasie het. Witooievaars word dikwels in groot swerms aangetref waar hulle op lugstrome sweef of op landerye wei (Sinclair \& Davidson, 1995:34). Tog is die vergelyking in Job 39:16 tussen die volstruis en die ooievaar nie primêr tussen die twee se vermoëns om te vlieg of nie, maar eerder hulle ouerskap (Van Deventer, 2009:727). Die ooievaar is bekend vir sy/haar goeie ouerskap en lojaliteit teenoor die kuikens in vergelyking met die volstruis wat in die antieke wêreld as 'n slegste ouer bekend gestaan het (Rowley, 1970:321).

Die primêre fokus van Job 39:16-21 is die renānîm (volstruis). Die letterlike vertaling van renānîm is "voël van deurdringende/skerp roep of skreeu" (Hartley, 1988:510). Hierdie volstruise (Struthio camelus syriacus) ${ }^{19}$ het in die semi-woestyngebiede, die

17 Die priesters van Baal het maskers van bulle in hulle tempeldiens gedra (Wolff, 1978[1974]:39).

18 Sien Ryken et al (1998:620) en Keel \& Uehlinger (1998[1992]:118).

19 Die sogenaamde Siriese volstruis het eers in die $20^{\text {ste }}$ eeu uitgesterf (Walton et al, 2000:510). Die laaste Siriese volstruis is blykbaar in Saoedi-Arabië gedurende die 
suide van Palestina, Arabië en Noord-Afrika bewoon (Hartley, 1988:510), tot so ver oos as die Eufraatrivier (Gordis, 1978:458). Die volstruis word in Job 39:16-21, aan die hand van populêre gesegdes, bygelowe en nie-wetenskaplike observasies, beskryf (Gordis, 1978:459). In die antieke wêreld is die volstruis as dwaas beskou (Pope, 1965:262). Job bevestig hierdie idee dat volstruise wreed (dwaas) is, deurdat hy sy vriende met hulle vergelyk en homself in die wildernis in afsondering saam met hulle ag (Job 30:29). Die volstruis word beskryf as 'n slegte ouer, wat geensins besorgd is oor sy/haar kuikens nie (Keel, 1978:68). ${ }^{20}$

Daar is ikonografiese beelde wat dui dat die teologiese tema van die "here van die volstruise" in die jare 900-700 vC in Israel en Juda aanwesig was (Keel \& Uehlinger 1998[1992]:182; Keel, 1978:102-103).

Die Edomitiese god Qos word ten nouste met die "here van die volstruise" geassosieer (Keel \& Uehlinger, 1998[1992]:385). ${ }^{21}$ Aangesien Qos geassosieer is met die land Edom en Job self 'n Edomiet was, is daar 'n moontlikheid dat die outeur van die boek Job, God hier (Job 39:16-21) binne die tradisie van die "here van die volstruise" plaas (Keel \& Uehlinger, 1998[1992]:385). Die "here van die volstruise" is in sy element in die wildernis (Keel \& Uehlinger, 1998[1992]:385, 140). Dit is juis hiér waar Jahwe vir die volstruis sorg.

Volstruise word gelys onder onrein voëls in Levitikus 11:16 en Deuteronomium 14:15. Die volstruis bewoon verlate plekke ${ }^{22}$ en verteenwoordig 'n verlate en gevaarlike wêreld (Keel \& Uehlinger, 1998[1992]:182; Berlin, 2004[2002]:106). Moontlik het die volstruis se bewoning van hierdie verlate (woestynagtige) gebiede iets te make met sy/haar onrein status, aangesien die woestyn en verlate plekke assosiasies met demone het (Keel \& Uehlinger, 1998[1992]:182). Volstruise kan 'n spoed van $60 \mathrm{~km}$ per uur bereik (Sinclair \& Davidson, 1995:76) en 'n spoed vir 1 kilometer handhaaf (Walton et al, 2000:510). Om hierdie rede is die volstruis beter toegerus om die resies teen die ruiter en perd te wen. Die volstruis word beskryf as 'n wrede en dwase dier en word met die sagmoedige ooievaar vergelyk. Tog beskik die volstruis oor die vermoë om die ruiter en sy perd uit te oorlê. Hoekom sal God 'n dier so vinnig maak, dat dit nie bruikbaar is vir die mens nie (Keel, 1978:84)? Tog is dit duidelik dat, ten

Tweede Wêreldoorlog deur Arabiere doodgemaak en geëet (Ferguson, 1974:47).

20 Die teenoorgestelde hiervan is waar.

21 In Edomitiese tempels waar die god, Qos aanbid is, is daar baie beeldjies van volstruise gevind (Knauf, 1999:675). Hiérdie feit plaas Qos binne die tradisie van die "here van die volstruise" en assosieer Qos met die woestyn, waar die volstruise hul tuiste vind (Knauf, 1999:675).

22 Sien Jes 13:21; 34:13; 43:20; Jer 50:39. 
spyte van die volstruis se sogenaamde tekortkomings aan wysheid, God steeds vir die volstruis sorg deur aan dié voël spoed te gee (Habel, 1975:215). In hierdie opsig boesem die volstruis respek in, aangesien dit kan oorleef in 'n wêreld wat op die grens is van die mens se bewoonbare habitat (Keel \& Uehlinger, 1998[1992]:182).

\section{Sprinkaan en perd (39:22-28)}

Job 39:23 verwys na die sprinkaan (arbeh). ${ }^{23}$ 'Arbeh se Hebreeuse stam is rābâ (baie/ groot menigte). Spreuke 30:27 spreek bewondering uit vir sprinkane se vermoë om leierloos hulleself te koördineer en saam in 'n swerm te beweeg. In hierdie opsig beskik sprinkane oor wysheid. Die 'arbeh in Spreuke 30:27 (en Job 39:23) is waarskynlik treksprinkane (Clifford, 1999:267). Hulle beskik oor 6 bene en 4 vlerke (Clifford, 1999:267). Oënskynlik leierloos, kom die sprinkane kwesbaar voor, tog vernietig hulle graan en beweeg met militêre presisie (Clifford, 1999:267). Levitikus 11:21 verbind die reinheid van sprinkane met hul vermoë om te kan spring. Die sprinkaan, met twee groot agterbene, die vermoë om te kan spring, asook vlerke om mee te vlieg, bring die diertjie in Ou-Testamentiese denke nader aan voëls as aan insekte (Wenham, 1979:175). Ten spyte van die rein klassifikasie is sprinkane steeds gevrees (Eks 10:1-20) en word met die woestyn geassosieer (Matt 3:3-4), wat ook negatiewe assosiasies het.

In Job 39:23 word sekere eienskappe van die perd en sprinkane teenoor mekaar geplaas. Die opgewondenheid en intense beweging van die perd ${ }^{24}$ word met dreunende sprinkane vergelyk (Wilson, 2007:445). Die primêre fokus van Job 39:2228 lê op die sûs (perd). Die perd wat hier ter sprake is, is die Arabiese perd (Equus caballus orientalis) (Ferguson, 1974:21). Die beskrywing van die perd in Job 39:2228 is deurspek met geweld (Odell, 1993:163). Die perd word saam met twee ander diere beskryf wat ook geweldadig voorkom, naamlik die volstruis en die sprinkaan (Odell, 1993:163). Die volstruis is indirek geweldadig teen haar kuikens en eiers terwyl die sprinkaan potensieel meer skade kan aanrig as leeus (Odell, 1993:163). Dit blyk dat die eerste interaksie tussen die perd en die volstruis (Job 39:21) ook met gewelddadige terme beskryf word, aangesien vers 21 heelwaarskynlik 'n volstruisjag beskryf (Odell, 1993:164). Die perd is gewillig om in hierdie geweld (jag) deel te neem, maar is terselfdertyd 'n slagoffer daarvan (Konkel 2006:227). In Job 39:22-

23 Nege verskillende woorde word in die OT gebruik om na verskillende sprinkane te verwys (Davies, 2008:18). Dit is nie altyd moontlik om die spesifieke sprinkaan of vorm daarvan te identifiseer nie (Davies, 2008:18).

24 Die perd is onrein (Houston, 1993:37), omdat dié dier se hoewe nie gesplete is nie (Deut 14:6). Die perd herkou ook nie. 
28 word die perd beskryf saam met die impak wat die mens op die perd het. Dit wil sê, die eerste direkte betrokkenheid van die mens in Job 39 word gekenmerk deur geweld (Odell, 1993:164; Konkel, 2006:227). Eerder as om die wêreld positief te beïnvloed, deurdrenk die mens die skepping met geweld.

Die perd en sprinkaan is albei potensiële bronne van geweld, maar is skepsels van God. Weereens bevestig dié paradoks in God se skepping die beperktheid van die mens se verstaansvermoë ten opsigte van - in hierdie geval - die etiek van geweld.

\section{Valk en aasvoël (39:29-33)}

In Job 39:29-33 val die fokus op twee roofvoëls. Die eerste hiervan is die ness (Job 39:29). Die Hebreeuse woord nēs kan vertaal word met "roofvoël”, heelwaarskynlik'n tipe valk (Falconidae). Die woord nēs verwys waarskynlik na alle valkagtige roofvoëls (Ferguson, 1974:53; Alden, 1993:390). Daar bestaan ten minste agtien verskillende spesies valke in Palestina (Reyburn 1992:734). Hierdie valk is waarskynlik Falco tinnunculus, aangesien dit die mees algemene migrerende valk in Palestina is (Alden, 1993:390).

Hierdie valke onderneem 'n jaarlikse migrasie met die roete wat deur Israel gaan (Ferguson, 1974:53). Job 39:29 se verwysing na die suide het waarskynlik te doen met hierdie jaarlikse migrasie van die valke deur Israel (Wilson, 2007:447). Die Hebreeuse woord vir suide (têmān) kan dus ook verwys na die Edomitiese stad Teman (Obad 9). ${ }^{25}$ Die antieke mens was beïndruk deur die migrasie van die voëls en sien daarin 'n bevestiging van geskape orde.

Die tweede roofvoël is die nesher. Die Hebreeuse woord nesher verwys moontlik na sowel die aasvoël as die arend (Ferguson, 1974:50; Hartley, 1992:159). Aangesien vers 33 verwys na die aantrekkingskrag van die nesher na dooie diere, verwys nesher hier eerder na die aasvoël (Figuur 4b). ${ }^{26}$ Waarskynlik kan die nesher van Job 39 met die witaasvoël (Gyps fulvis) identifiseer word (Hartley, 1992:159). Alhoewel die meeste onrein voëls roofvoëls/aasvoëls is, is daar geen direkte rede hoekom hierdie voëls onrein geklassifiseer word nie (Hartley, 1992:159). ${ }^{27}$ Onreinheid het te make met dood (Kiuchi, 2007:196). Moontlik word die assosiasie tussen aasvoëls,

25 Alhoewel Teman tradisioneel met 'n groot area geassosieer word, kan Teman ook moontlik met die hedendaagse dorpie Tuwilan, noord-oos van die dorpie El-dji assosieer word (Wolff, 1986[1977]:52).

26 Die LXX het nesher met aasvoël (áetós) vertaal.

27 Sien Thompson (1974:87) en Craigie (1976:232). 
lyke (voedsel) en dus die doderyk in die antieke mens se verwysingsraamwerk onafskeidbaar.

Aasvoëls woon op rotse en kranse (Job 39:31), buite die bereik van mense en dien geen doel vir die mens nie (Alden, 1993:391). Tog skenk God besondere vermoëns en wysheid aan hierdie twee roofvoëls. Dit is nie deur Job se toedoen dat die valk of die aasvoël vlieg nie. So ook is dit nie Job wat die valk die wysheid skenk om te besef om te migreer nie. Voëls ken die orde van die skepping en lewe daarbinne (Bright, 1965:63). Hierdie feit word bevestig deur die ordelike migrasie van voëls. Die verbod op die eet van bloed, versteur nie God se trots in die aasvoël nie. Etiese kwessies oor reg en verkeerd is in die skepping ingeweef en eenvoudige antwoorde blyk daar nie te wees nie. God se koningskap word nie deur die valksimboliek van Horus belemmer nie. ${ }^{28}$ God is dié een wat aan die valk wysheid gee. Die vermoë van klein diertjies (valk en aasvoël) om met wysheid te lewe plaas Job se wysheid in die kollig, aangesien Job nie hiérdie selfde insigte tot wysheid toon nie.

\section{OPSOMMINGVAN DIERE TER INLEIDING TOT DIE GEVOLGTREKKING}

Hier volg 'n opsomming van die diere genoem:

- Die ibis is woonagtig in die "wildernis" en is onrein volgens kultiese wette, maar geniet God se seën en sorg deurdat God dit wysheid skenk.

- Alhoewel die haan volgens die reinheidskodes van Levitikus 11 as rein beskou word en deel van die voedselvoorraad van voor-ballingskapse Israel uitmaak, toon die haan steeds sterk Rabbiniese assosiasies met onreinheid. Die haan is woonagtig op die grens tussen "samelewing" en "wildernis", maar geniet God se seën en sorg deurdat God dit wysheid skenk.

- Die leeu is 'n bedreiging vir lewe en word dus met die dood en bedreiging van die orde in die antieke wêreld geassosieer. Die leeu is woonagtig in die "wildernis" en is kulties as onrein beskou, maar geniet God se sorg in die boek Job.

- Die kraai is woonagtig in die "wildernis", eet dooie diere en word dus met die dood geassosieer. Die kraai is ook kulties onrein, maar geniet God se sorg.

28 Die Egiptiese god, Horus is ten nouste met die valk geassosieer (Wyatt 2001:214; Walton, 2007:340). Horus is die inkarnasie van elke Farao (Wyatt, 2001:214) en in dié opsig is die Egiptiese koninklike bloedlyn met die valk geassosieer. 
- Die ibeks en die hert is in die "wildernis" woonagtig en rein, maar kulties uitgesluit, aangesien dit geëet mag word, maar nie geoffer mag word nie. Tog geniet hierdie diere God se sorg.

- Die wildedonkie is woonagtig in die "wildernis" en kulties onrein. Nietemin is dit God wat vir hierdie dier sorg deur hom sy vryheid te bied.

- Die buffel is in die "wildernis" woonagtig en rein. Hierdie dier is gevaarlik en 'n bedreiging vir mense en het dus negatiewe assosiasies. Tog sorg God vir hierdie dier deur vir die buffel krag te gee.

- Die ooievaar woon in die wildernis en is kulties onrein. Hierdie dier eet ander diere en word kulties geassosieer met die dood. Tog sorg God vir die ooievaar deur hierdie voël te laat vlieg.

- Die volstruis woon in die 'wildernis', is kulties onrein en is die slagoffer van 'n magdom negatiewe assosiasies. Tog skenk God hierdie dier baie spoed vir oorlewing.

- Die sprinkaan woon in die "wildernis" en die oorsaak van ergerlike vernietiging. Die sprinkaan word dus ten diepste met die dood geassosieer. Die sprinkaan is egter rein en geniet God se sorg deurdat dit oënskynlik leierloos met militêre presisie kan voortbeweeg.

- Die perd se habitat is die oorlogsveld (wildernis) en word dus met dood en geweld geassosieer en is ook kulties onrein. Nietemin skenk God die perd die temperament om in hierdie lewe te floreer.

- Die valk en die aasvoël eet ander diere en word dus met die dood geassosieer. Hulle is ook kulties onrein en woon in die "wildernis". Tog sorg God vir hulle deur hulle onderskeidelik wysheid te gee om te migreer en goeie sig om voedsel te kry.

\section{GEVOLGTREKKING}

Interessant om te sien dat die enigste diere wat rein is, diere is wat sterk assosiasies met gedomestiseerde diere het wat in die "samelewing" woon. Byvoorbeeld, die haan en ibeks/hert (gedomestiseerde bokke), buffel (gedomestiseerde bees) en die sprinkaan (hierdie dier word kulties eerder geassosieer met 'n eetbare voël). Die afleiding is dus dat "binne die samelewing" gepaard gaan met goeie assosiasies, want dit is beheerbaar en verstaanbaar. Andersyds het die wildernis negatiewe assosiasies, want dit is onbeheerbaar, onverstaanbaar en 'n bedreiging tot lewe. 
Die diere in Job 38-39:33 toon kenmerkende eienskappe met betrekking tot waar hierdie diere woonagtig is, sowel duidelike assosiasies met die dood. Die assosiasies met dood en 'n natuurlike habitat wat buite die grense van "samelewing" is word sterk met onreinheid geassosieer. Soos die dood self word habitat buite die "samelewing" geassosieer met dit wat buite die verstaanvermoë en beheer van die antieke mens was. Onreinheid word dus geassosieer met die onvermoë om te verstaan en die ervaring van geen beheer hê nie. Om in die "wildernis" te woon het assosiasies met die dood en om hierdie rede het al die diere in Job 38:39-33 assosiasies met onreinheid. Onreinheid, habitat (wildernis) en assosiasies met die dood is dus met mekaar verweef en beskryf die menslike ervaring van "nie verstaan nie" en "buite beheer wees".

Kultiese reinheid en onreinheid word onderskeidelik aan kulturele denkprosesse gekoppel wat reinheid met orde en God se teenwoordigheid assosieer. Hierdie area waar reinheid, orde en God se teenwoordigheid heers, word "samelewing" genoem. Die antitese van "samelewing" is die "wildernis". "Wildernis" word gekoppel aan onreinheid, chaos en demoniese teenwoordigheid. Reinheid en onreinheid is bepalende faktore om die grense tussen "samelewing" en "wildernis". In Job $38-41$ word God se sorg beskryf aan die hand van diere wat die "wildernis" bewoon. Israel se negatiewe assosiasies met "wildernis" (dus onreinheid) in Job 38 - 41 staan dus nou direk teen God se positiewe assosiasie en sorg van "wildernis" (onreinheid). Job en die leser se persepsie van reinheid en onreinheid word deur die outeur(s) uitgedaag. Hierdeur bied die boek Job 'n nuwe perspektief rondom die etiek van lyding.

God se teenwoordigheid oor ruimtes waar die mens nie beheer het nie en deurdrenk is met negatiewe assosiasies, dus ook lyding in die lewe van die mens, word bevestig. God is soewerein oor alle aspekte van lewe, nie net aspekte wat positiewe menslike assosiasies insluit nie.

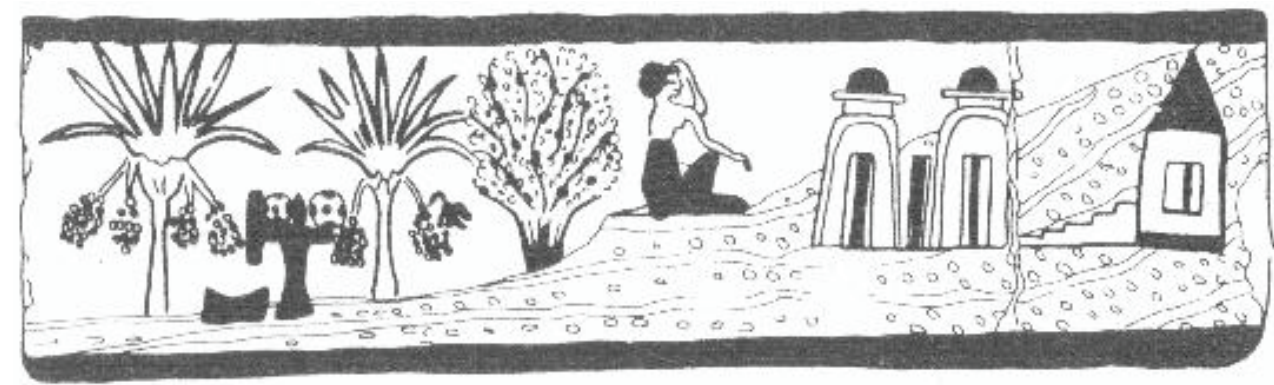


Hierdie figuur is 'n geverfde uitbeelding (elfde tot negende eeu vC, Kaïro) van die woestyn (Keel, 1997[1972]:76). Links is daar drie bome wat vrugte dra. Onder die drie bome is daar 'n altaar en 'n bak om ritueel te was. Regs is daar die woestyn en in die woestyn is daar grafte. Die woestyn word onderskei deur die afwesigheid van vrugbaarheid asook assosiasies met die dood. Die individu sit op die grens tussen die vrugbare "samelewing" en die onvrugbare "wildernis". Dit is duidelik dat die woestyn (regs) nie met vrugbaarheid (lewe) geassosieer word nie, maar eerder met dood (dus onreinheid). Die wildernis (regs) word dus die versimbolisering van onreinheid en dood en die samelewing (links) versimboliseer reinheid en lewe.

Die boek Job is relevant met betrekking tot die teodisee-vraagstuk, omdat God tog reageer op Job se aanklagte dat God 'n antwoord op lyding moet gee. In dié sin is die teologiese doel van die boek om aan te toon dat God aanwesig is tydens menslike lyding (Rowley, 1970:20-21), maar nie om 'n antwoord op die vraag na menslike lyding te gee nie (Rowley, 1970:19). Wat vir die mens moontlik goed of boos mag voorkom, is beperk tot die perspektief van die mens (Keel, 1978:61). Die aktualiteit van die boek Job is daarin geleë dat die mens tot nuwe perspektiewe tydens lydingservarings kan kom. In hierdie opsig dien God se sorg vir die "wildernis" en inwoners van die "wildernis" as uitdaging tot die mens se persepsies van "goed" en "kwaad", dus die plek van lyding in die lewe van mense. Lyding, oënskynlik verdien of dan nie, kan dus nie met negatiwiteit en die "kwaad" geassosieer word nie, aangesien God soewerein oor sowel "goed" en "kwaad" troon.

\section{BIBLIOGRAFIE}

Alden, RL 1993. Job. The New American Commentary, vol 11. Nashville, Tennesse: Broadman Holman Publishers.

Andersen, FI 1976. Job: An Introduction and Commentary. Tyndale Old Testament Commentaries. Leicester, England: Inter-Varsity Press

Anderson, GA 1992. S v Sacrifice and Sacrificial Offerings. 870-886. In: Freedman, DN et al (Eds) 1992. Anchor Bible Dictionary, vol 5. Garden City, New York: Doubleday.

Berlin, A 2004 [2002]. Lamentations: A Commentary. Old Testament Library. Louisville, Kentucky: Westminster John Knox Press.

Boshoff, W, Scheffler, E \& Spangenberg, S 2000. Ancient Israelite Literature in Context. Pretoria: Protea Bookhouse. 
Bright, J 1965. Jeremiah: Introduction, translation and notes. The Anchor Bible. Garden City, New York: Doubleday and Company Inc.

Brueggemann, 2003. An Introduction to the Old Testament: The Canon and the Christian Imagination. Louisville, Kentucky: Westminster, John Knox Press.

Clifford, R J 1999. Proverbs: A Commentary. The Old Testament Library. Louisville: Westminster John Knox Press.

Clines, D J A 1989. Job 1-20. Word Biblical Commentary, vol 17. Dallas, Texas: Word Books Publisher.

Craigie, P C 1976. The Book of Deuteronomy. The New International Commentary on the Old Testament. Grand Rapids, Michigan: WB Eerdmans.

Crenshaw, J L 1981. Old Testament Wisdom: An Introduction. Bloomsbury street, London: SCM.

--- 1992. S v Job, Book of. 868-901. In: Freedman, D N et al (Eds). Anchor Bible Dictionary, vol 3. Garden City, New York: Doubleday.

Davies, PT 2008. S v Animal Imagery, 13-20. In: Longman III, T \& Enns, P (Eds). Dictionary of the Old Testament: Wisdom, Poetry and Writings. Downers Grove, Illinois: Intervarsity Press.

Dick, M B 2006. The Neo-Assyrian Royal Lion Hunt and Yahweh's Answer to Job. Journal of Biblical Literature, vol 2, 243-270.

Ferguson, W W 1974. Living Animals of the Bible. New York: Charles Scriber's Sons.

Firmage, E 1992. S v Zoology (Fauna), 1109-1167, vol 6. In: Freedman, D N et al (Eds). Anchor Bible Dictionary, vol 1-6. Garden City, New York: Doubleday.

Gordis, R 1965. The Book of God and Man: A Study of Job. Chicago: The University of Chicago Press.

--- 1978. The Book of Job: Commentary, New Translation and Special Studies. New York: The Jewish Theological Seminary of America.

Habel, NC 1975. The Book of Job. Cambridge Bible Commentary. Bentley House, London: Cambridge University Press.

--- 1985. The Book of Job. Old Testament Library. Bloomsbury Street, London: SCM. 
Hartley, JE 1988. The Book of Job. New International Commentary on the Old Testament. W. B. Eerdmans: Grand Rapids, Michigan.

--- 1992. Leviticus. Word Biblical Commentary, vol 4. Dallas, Texas: Word Books Publisher.

Houston, W 1993. Purity and Monotheism: Clean and Unclean Animals in Biblical law. JSOT. Supplement Series 140. Sheffield: Sheffield Academic Press.

Keel, O 1978. Jahwes Entgegnung an Ijob: Eine Deutung von Ijob 38-41 vor dem Hintergund der zeitgenössischen Bildkunst. Göttingen: Van den Hoeck \& Ruprecht.

--- 1997 [1972]. The Symbolism of the Biblical World: Ancient Near Eastern Iconography and the Book of Psalms. Winona Lake, Indiana: Eisenbrauns.

--- 1998. Goddesses and Trees, New Moon and Yahweh: Ancient Near Eastern Art and the Hebrew Bible. JSOT, Supplement Series 261. Sheffield: Sheffield Academic Press.

Keel, O \& Uehlinger C 1998 [1992]. Gods, Goddesses, and Images of God: In Ancient Israel. Minneapolis: Augsburg Fortress Press.

Kiuchi, N 2007. Leviticus. Apollos Old Testament Commentary. Downers Grove, Illinois: Intervarsity Press.

Knauf, EA 1999. S v Qos, 674-677. In: Van der Toorn, K, Becking, B \& Van der Horst, P W (Eds) 1999. Dictionary of Deities and Demons in the Bible: DDD. Second Extensively Revised Edition. Grand Rapids, Michigan: W. B. Eerdmans.

Konkel, A H 2006. Job. 2-249. In: Konkel, A H \& Longman III, T. Job, Ecclesiastes \& Song of Songs. Cornerstone Biblical Commentary. Carol Stream, Illinois: Tyndale House Publishers Inc.

Matthews, VH \& Moyer, JC 1997. The Old Testament: Text and Context. Peabody, Massachusetts: Hendrickson Publishers Inc.

Murphy, RE 1981. Wisdom Literature: Job, Proverbs, Ruth, Canticles, Ecclesiastes, and Esther. Forms of the Old Testament Literature, vol 13. Grand Rapids, Michigan: W. B. Eerdmans.

Odell, D 1993. Images of Violence in the Horse in Job 39:18-25, 166-173. Prooftexts, vol 13. Baltimore, Maryland: John Hopkins University Press.

Pope, MH 1965. Job: Introduction, Translation and Notes. Anchor Bible. Garden City, New York: Doubleday \& Company Inc. 
Porter, JR 1976. Leviticus. Cambridge Bible Commentary. Cambridge: Cambridge University Press.

Reyburn, WD 1992. A Handbook on the Book of Job. Broadway, New York: United Bible Societies.

Rowley, HH 1970. Job. New Century Bible. Ontario, Canada: Thomas Nelson \& Sons Ltd.

Ryken, L, Wilhoit, JC \& Longman III, T (Eds) 1998. S v Animals, 26-32. In: Dictionary of Biblical Imagery. Downers Grove, Illinois: IVP Academic.

--- 1998. S v Ox, 620-621. In: Dictionary of Biblical Imagery. Downers Grove, Illinois: IVP Academic.

Sinclair, I \& Davidson, I 1995. Suid-Afrikaanse Voëls: 'n Fotografiese Gids, SASOL. Kaapstad: Struik.

Thompson, JA 1974. Deuteronomy. Tyndale Old Testament Commentaries. Downers Grove, Illinois: Intervarsity Press.

Van Deventer, H 2009. Job. In: Van Rensburg, F J \& Nel, M (Reds) 2009. Die Bybellenium: ' $n$ Een volume Kommentaar, Die Bybel uitgelê vir eietydse toepassing. 676-731. Vereeniging: Christelike Uitgewersmaatskappy.

Von Rad, G 1972. Wisdom in Israel. Old Testament Library. Bloomsbury Street, London: SCM.

Walton, J H 2007. Ancient Near Eastern Thought and the Old Testament: Introducing the Conceptual World of the Hebrew Bible. Nottingham: Apollos.

Walton, JH, Matthews, VH \& Chavalas, MW 2000. The IVP Bible Background Commentary: Old Testament. Downers Grove, Illinois: Intervarsity Press.

Wenham, GJ 1981. Numbers. Tyndale Old Testament Commentaries. Downers Grove, Illinois: Inter-Varsity Press.

Wilson, GH 2007. Job. New International Biblical Commentary: Old Testament Series. Peabody, Massachusetts: Hendrickon Publishers Inc.

Wolff, HW 1978[1974]. Hosea: A Commentary on the Book of the Prophet Hosea. Hermeneia - A Critical and Historical Commentary on the Bible. Philadelphia: Fortress Press. 
Wood, J 2009 [1869]. Bible Animals: A Description of Every Creature Mentioned in the Scriptures From the Ape to the Coral. London: Longmans, Green, Reader, and Dyer.

Wyatt, N 2001. Space and Time in the Religious Life of the Near East. Sheffield: Sheffield Academic Press.

Yancey, P 1990 [1977]. Where is God when it hurts? Grand Rapids, Michigan: Zondervan. 